\title{
CENTRAL VENOUS BLOOD AS AN INDEX OF ACID-BASE AND OXYGENATION STATUS
}

\author{
P. R. RamachandRan, M.B., B.S., H. B. FaIRLEY, M.B., B.S., F.F.A.R.C.S., AND \\ A. K. LAWS, B.SC., M.B., B.S., F.F.A.R.C.S. ${ }^{*}$
}

THE MOST GENERALLY ACCEPTED laboratory approach to the evaluation of acid-base status and of oxygenation is by examination of arterial blood. This makes certain assumptions with respect to tissue and organ perfusion gradients between capillaries and tissue, and these are most valid in the steady state. However, the great merit of using arterial blood lies in the fact that it indicates respiratory status at the pulmonary gas exchange level.

Arterial puncture is usually without serious hazard, although occasional instances of subsequent arterial occlusion have been described, particularly when the need for repeated sampling has dictated the use of indwelling arterial cannulae. This problem, coupled with the relatively greater difficulty of arterial sampling in certain types of patients such as infants and the grossly obese, has stimulated the validation of results derived from capillary ${ }^{1-5}$ and from peripheral venous $^{2,6-8}$ blood, when used as indirect indices of arterial acid-base status. Only one previous paper has described the validity of results derived from central venous pressure line samples, obtained in that instance from patients in a shock unit. ${ }^{9}$

Under ideal sampling circumstances, acid-base values derived from capillary or peripheral venous samples are very close to those of arterial blood, whereas central venous hydrogen ion concentration and carbon dioxide tension will differ by a definable amount from their arterial counterparts. It is the primary purpose of this paper to define the average arterial-central venous difference (a-cv $\Delta$ ) and to examine any error which may be inherent in the routine use of such correction factors.

The additional proposition has frequently been made that examination of mixed or central venous blood may be a useful index of tissue oxygenation, since the interaction of tissue consumption and arterially delivered oxygen is the determinant of venous oxygen content. In consequence, a secondary aim of this study was to examine the correlation between central venous oxygen levels and our more usual indices of oxygenation-their arterial counterparts.

\section{Material and Methods}

A total of 56 simultaneously drawn samples of arterial and central venous blood were obtained from 25 unselected patients in a respiratory failure unit. There were 18 male and 7 female patients, ranging in age from 17 to 71 years, the mean being 51 years (Table I). In each patient the central venous pressure was being monitored by a large catheter, inserted in the median basilic or the

-Department of Anaesthesia, University of Toronto. 
TABLE I

Ages and Diagnoses of Patients Included in Study

\begin{tabular}{|c|c|c|}
\hline Patient & Age & Diagnosis \\
\hline 1 & 49 & pneumonia, congestive heart failure, old right thoracoplasty \\
\hline 2 & 58 & lung abscess, old thoracoplasty \\
\hline 3 & 48 & polyneuritis, bronchopneumonia \\
\hline 4 & 37 & post-thoracotomy for tracheal graft \\
\hline 5 & 19 & pulmonary embolism \\
\hline 6 & 51 & bronchial asthma \\
\hline 7 & 67 & myasthenia gravis \\
\hline 8 & 56 & emphysema \\
\hline 9 & 20 & staph. pneumonia \\
\hline 10 & 69 & pneumonia, chronic chest disease \\
\hline 11 & 55 & bronchitis and emphysema \\
\hline 12 & 64 & fractured pelvis, crushed chest, head injury \\
\hline 13 & 71 & respiratory failure following bowel resection \\
\hline 14 & 40 & myasthenia gravis (post thymectomy), pneumonia \\
\hline 15 & 61 & $\begin{array}{l}\text { respiratory failure following thoraco-abdominal } \\
\text { oesophagectomy and colon transplant }\end{array}$ \\
\hline 16 & 36 & cerebral oedema following craniotomy \\
\hline 17 & 17 & crushed chest and lobectomy \\
\hline 18 & 30 & cerebral oedema following head injury and decompression \\
\hline 19 & 61 & encephalitis, renal failure, pneumonia, old bronchiectasis \\
\hline 20 & 65 & cerebral oedema following cardiac arrest \\
\hline 21 & 64 & emphysema \\
\hline 22 & 67 & $\begin{array}{l}\text { stove-in chest, facial smash, multiple injuries, broncho- } \\
\text { pneumonia }\end{array}$ \\
\hline 23 & 43 & chronic bronchitis and emphysema \\
\hline 24 & 61 & drug overdosage, diabetes \\
\hline 25 & 59 & emphysema and pneumothorax \\
\hline
\end{tabular}

femoral vein. The tip of the catheter, as determined by X-ray, was located in the right atrium in three, in the superior vena cava in thirty-nine, in the inferior vena cava in six, in the right subclavian vein in six, and in the innominate vein in two of the samples.

The central venous blood was obtained after emptying the deadspace of the catheter and, simultaneously, the arterial blood was drawn from the femoral or radial artery. The samples were immediately analysed at $37^{\circ} \mathrm{C}$. for $\mathrm{pH}, \mathrm{PCO}_{2}$, and $\mathrm{Po}_{2}$ using Metrohm $\mathrm{pH}$, Severinghaus carbon dioxide, and Radiometer oxygen electrodes, and for haemoglobin concentration by a Beckman DB spectrophotometer.

From these values, the base excess was determined using the Siggaard-Andersen alignment nomogram, and oxygen saturation was determined using the Radiometer blood gas calculator. ${ }^{10}$ Base excess values were then corrected for oxygen saturation, using the factor recommended by Siggaard-Andersen. ${ }^{11}$ Oxygen content was calculated, using a haemoglobin oxygen capacity of $1.34 \mathrm{ml} . / \mathrm{gm}$. $\mathrm{Hg}$ and an oxygen solubility coefficient of 0.0031 . Hydrogen ion concentration $\left[\mathrm{H}^{+}\right]$in nanomoles/L. was derived from the negative antilogarithm of the $\mathrm{pH} \times 10^{9}$.

The difference between duplicated samples in this laboratory is as follows: $\mathrm{pH}(\mathrm{n}=200): \mathrm{m} \Delta=+0.001, \mathrm{SD}= \pm 0.004$ $\mathrm{PCO}_{2}(\mathrm{n}=200): \mathrm{m} \Delta=+0.2 \mathrm{~mm}$. Hg, SD $= \pm 0.3 \mathrm{~mm}$. Hg $\mathrm{Po}_{2}(0-100 \mathrm{~mm} . \mathrm{Hg})(\mathbf{n}=200): \mathrm{m} \Delta=-0.1 \mathrm{~mm} . \mathrm{Hg}, \mathrm{SD}= \pm 0.3 \mathrm{~mm} . \mathrm{Hg}$ $\mathrm{Po}_{2}(100-200 \mathrm{~mm} . \mathrm{Hg})(\mathrm{n}=29): \mathrm{m} \Delta=-0.2 \mathrm{~mm} . \mathrm{Hg}, \mathrm{SD}= \pm 0.7 \mathrm{~mm} . \mathrm{Hg}$ $\mathrm{Hgb}(\mathbf{n}=30): \mathrm{m} \Delta=+0.03 \mathrm{gm} . \%, \mathrm{SD}= \pm 0.1 \mathrm{gm} . \%$ 


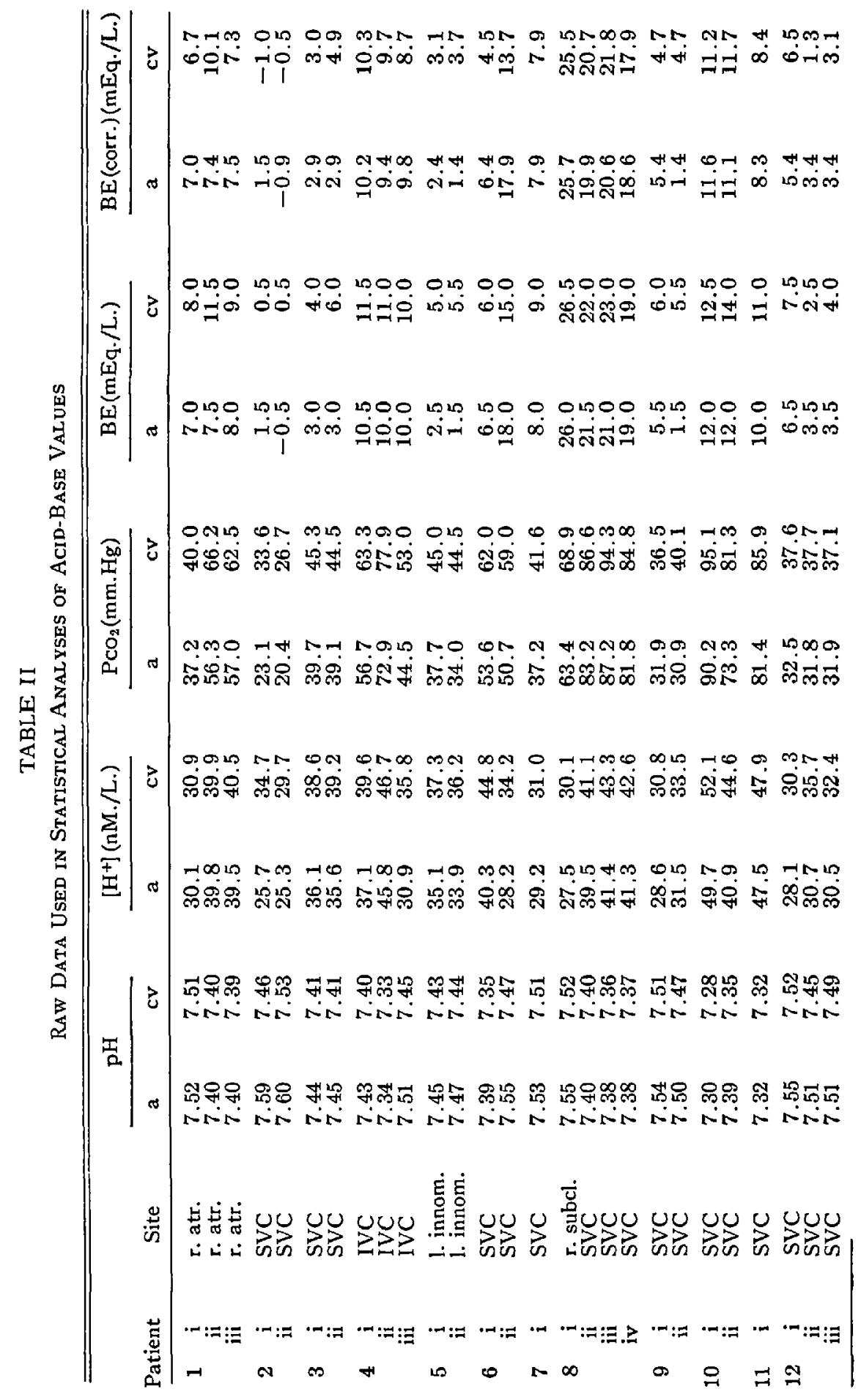




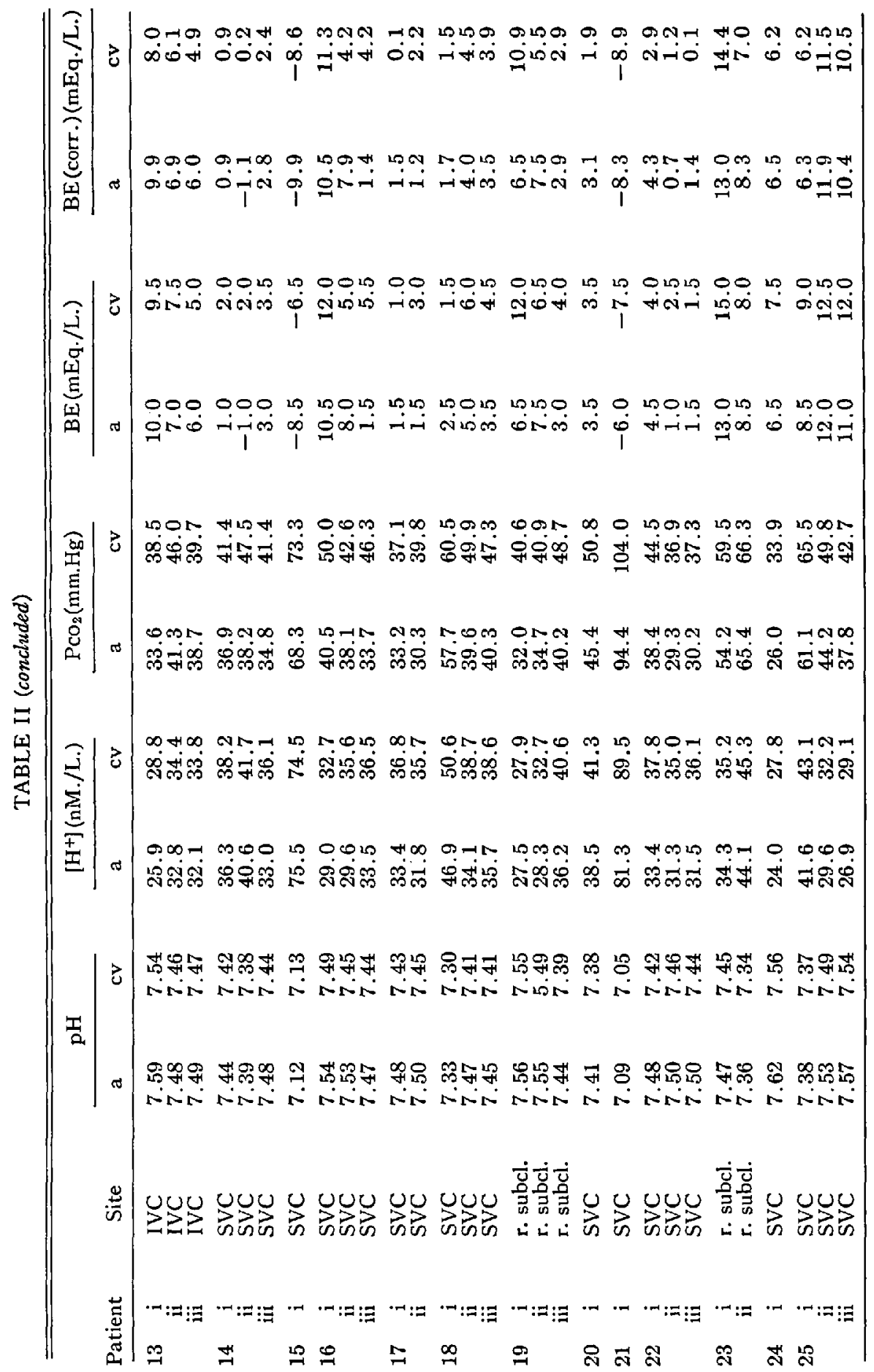



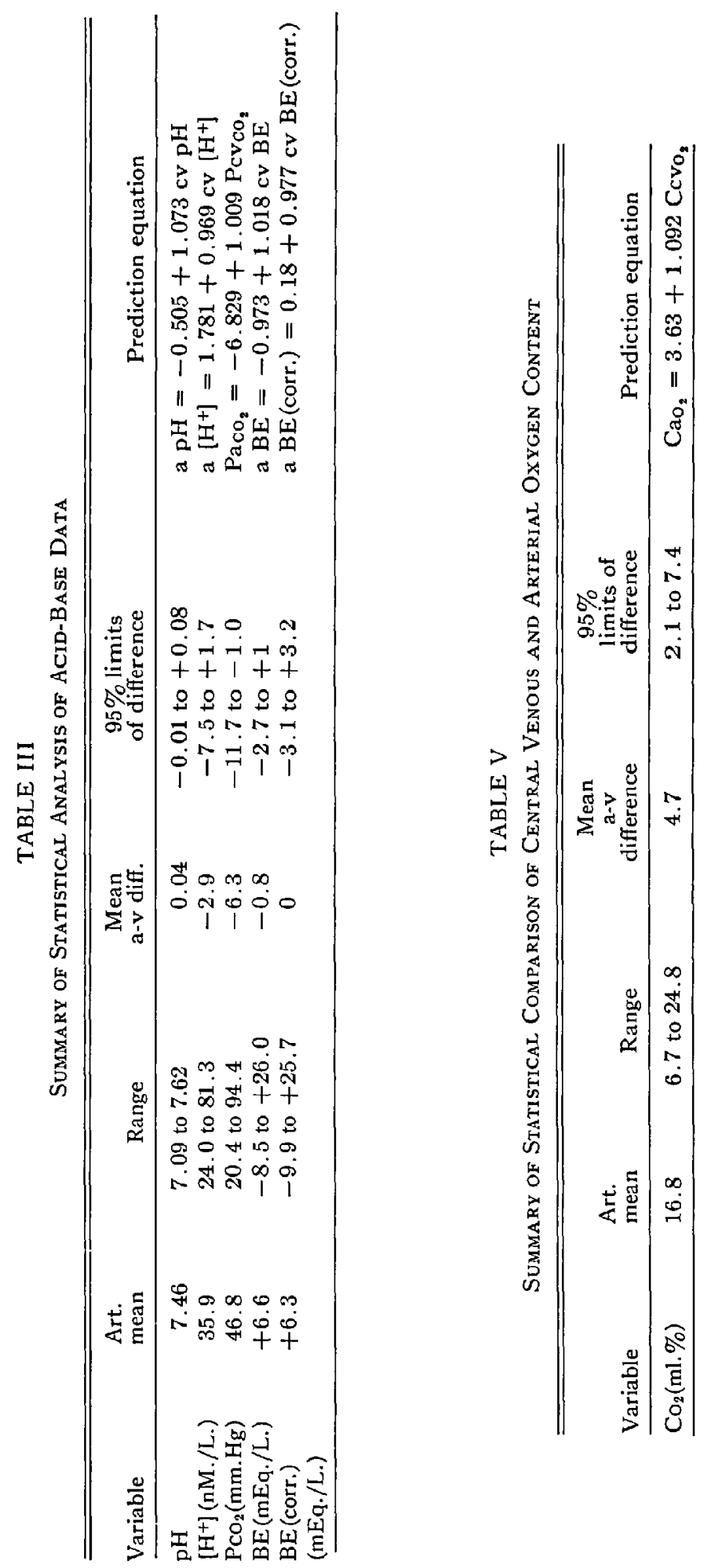
TABLE IV

Raw Data Used in Statistical Analyses of Oxygenation Values

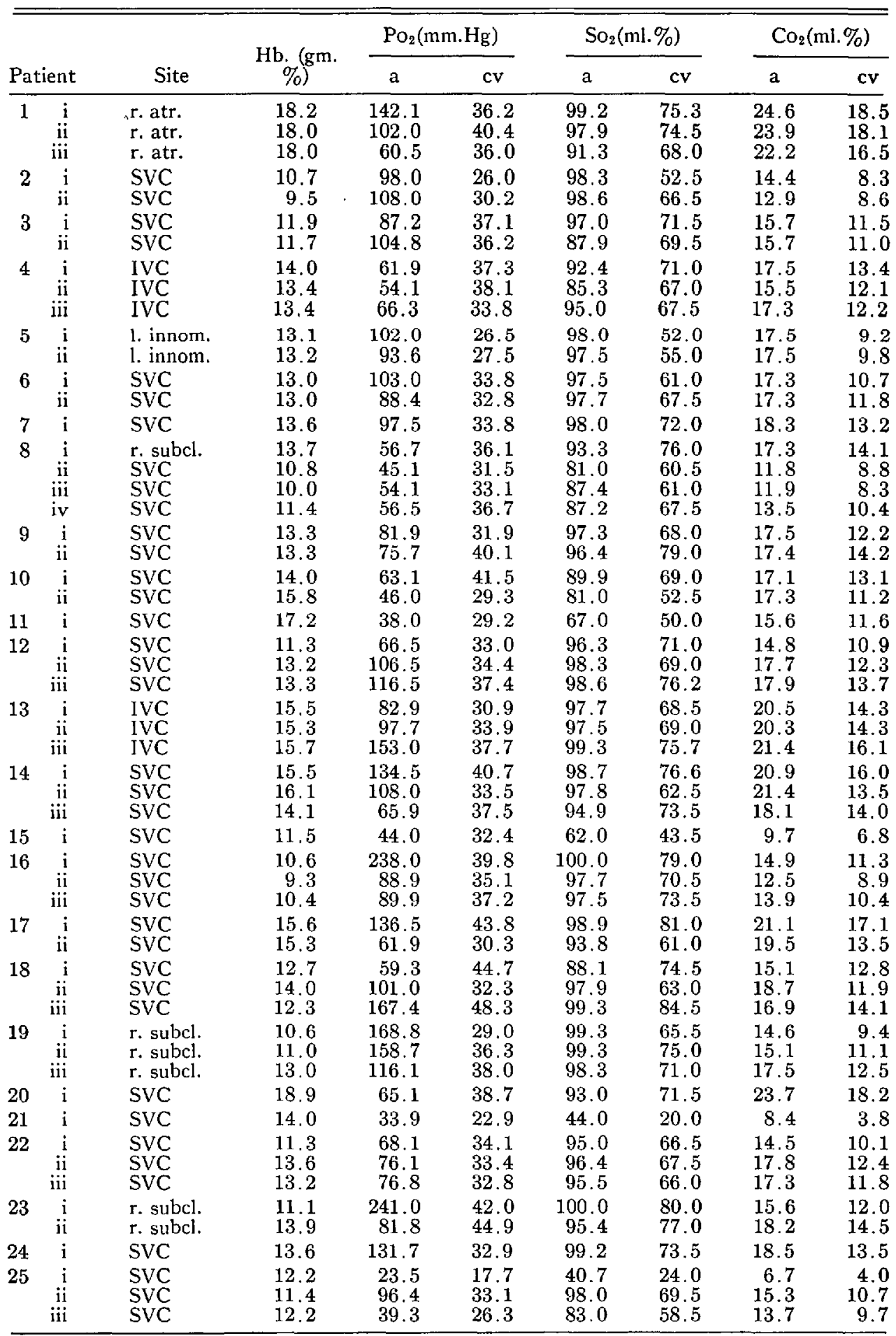




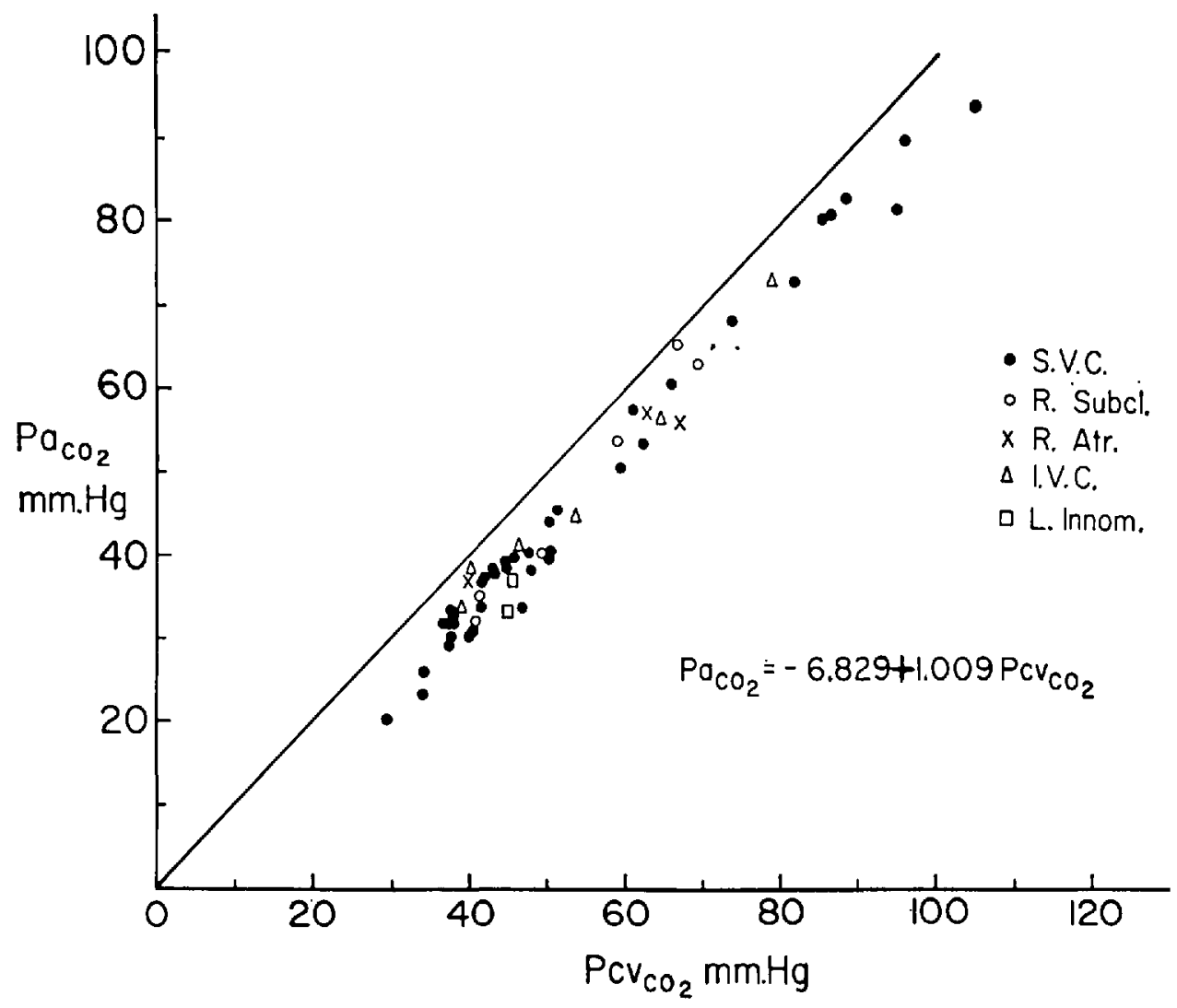

Frgure 1. Comparison of arterial and central venous values for carbon dioxide tension, with their regression equation.

\section{Results}

Each central venous value was compared with the figure for arterial blood sampled simultaneously (Tables II and IV, Figures 1-8). The statistical population studied was not homogenous and independent, in that the sampling site was not constant and differing numbers of samples were taken from each patient. However, examination of the plots displayed no obvious bias introduced by the various sampling sites, and each sampling occasion, in a given patient, was considered a potentially new set of acid-base and oxygenation circumstances, since no more than one pair of samples was taken on any given day. For these reasons, all samples were included in the analyses.

Good correlation was observed between arterial and central venous values for $\mathrm{PCO}_{2}$, base excess, $\mathrm{pH},\left[\mathrm{H}^{+}\right]$, and oxygen content, and these were subjected to regression analysis. The results for the mean arterial value, range studied, mean a-cv $\Delta$ and the 95 per cent confidence limits are presented with the relevant prediction equations in Tables III and V. The lack of correlation between arterial and central venous values for oxygen saturation and tension, evident in Figures 7 and 8, discouraged calculation of predictions for these variables. 


\section{Discussion}

The mean a-cv $\Delta$ values for $\mathrm{pH}(0.04)$ and $\mathrm{PcO}_{2}(6.3 \mathrm{~mm} . \mathrm{Hg})$ noted in this study are comparable to the mean arterial-mixed venous differences reported by Cournand and his colleagues from right heart catheterization samples $(\mathrm{pH}=0.03$, $\mathrm{PCO}_{2}=5.4 \mathrm{~mm} . \mathrm{Hg}$ ). ${ }^{12}$ They differ from those reported by Zahn and Weil $(\mathrm{pH}=$ $0.011, \mathrm{PCO}_{2}=3.74 \mathrm{~mm}$. $\left.\mathrm{Hg}\right),{ }^{9}$ probably because of the different type of patients studied. In addition, the latter group quoted a mixed venous $\mathrm{PCO}_{2}$ below arterial levels-a typographical error.

The usefulness of prediction equations depends upon the scatter of values when this is related to their clinical significance. The 95 per cent confidence limits indicate this scatter and are most valid at the mean arterial value.

The scatter in Figure $I$ is probably sufficiently small to permit the clinical use of central venous $\mathrm{PCO}_{2}$ values. The mean a-cvs and the 95 per cent confidence limits (Table III) show that a central venous $\mathrm{PCO}_{2}$ of, say, $46 \mathrm{~mm}$. $\mathrm{Hg}$ would give a predicted arterial level of $40 \mathrm{~mm}$. $\mathrm{Hg}$ when, on 95 per cent of such occasions, the true arterial value would lie between 34 and $45 \mathrm{~mm}$. Hg. Thus, for clinical purposes, one is unlikely to be seriously misled by conclusions drawn from a

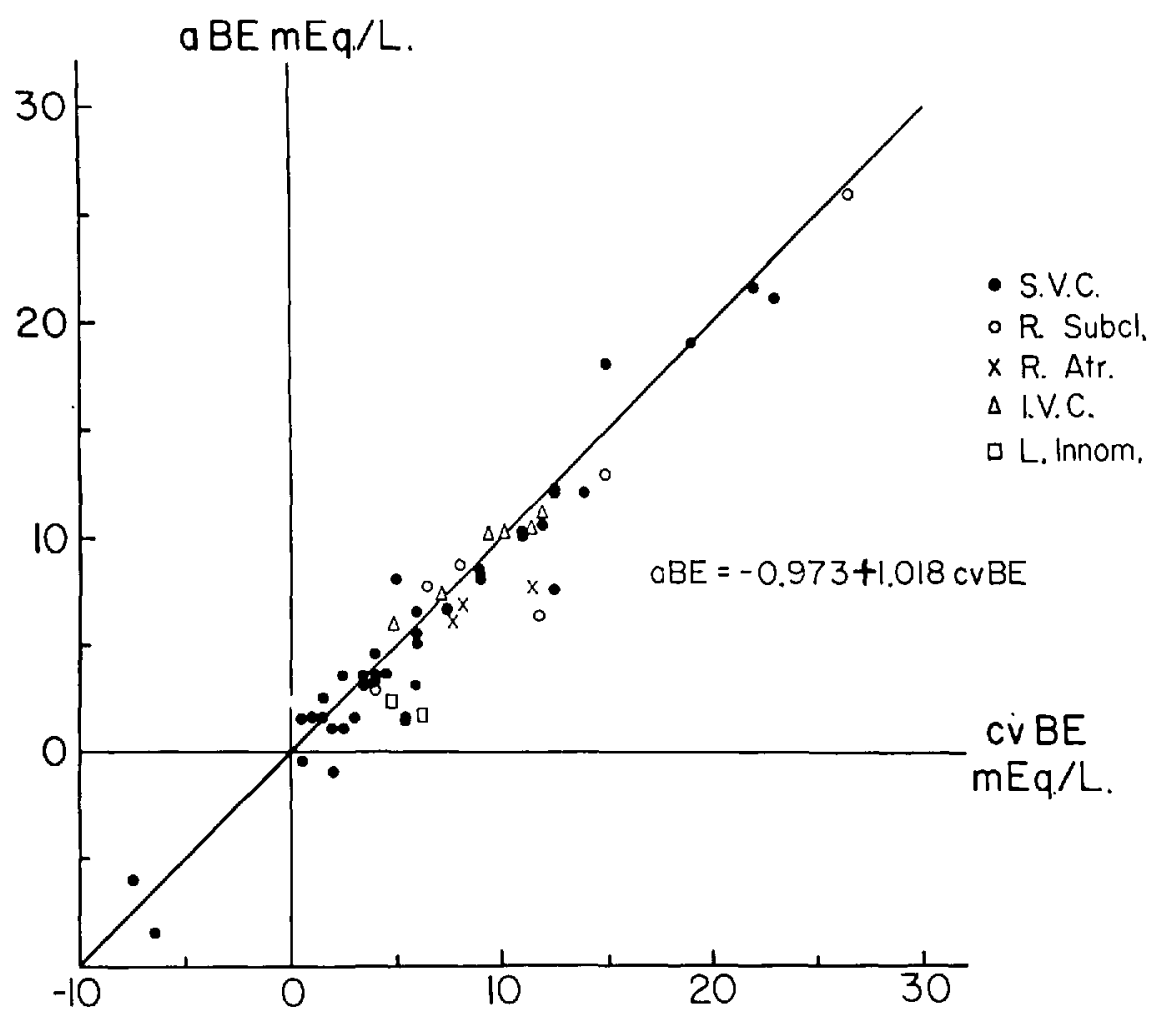

Frgure 2. Comparison of arterial and central venous values for base excess, with their regression equation. 


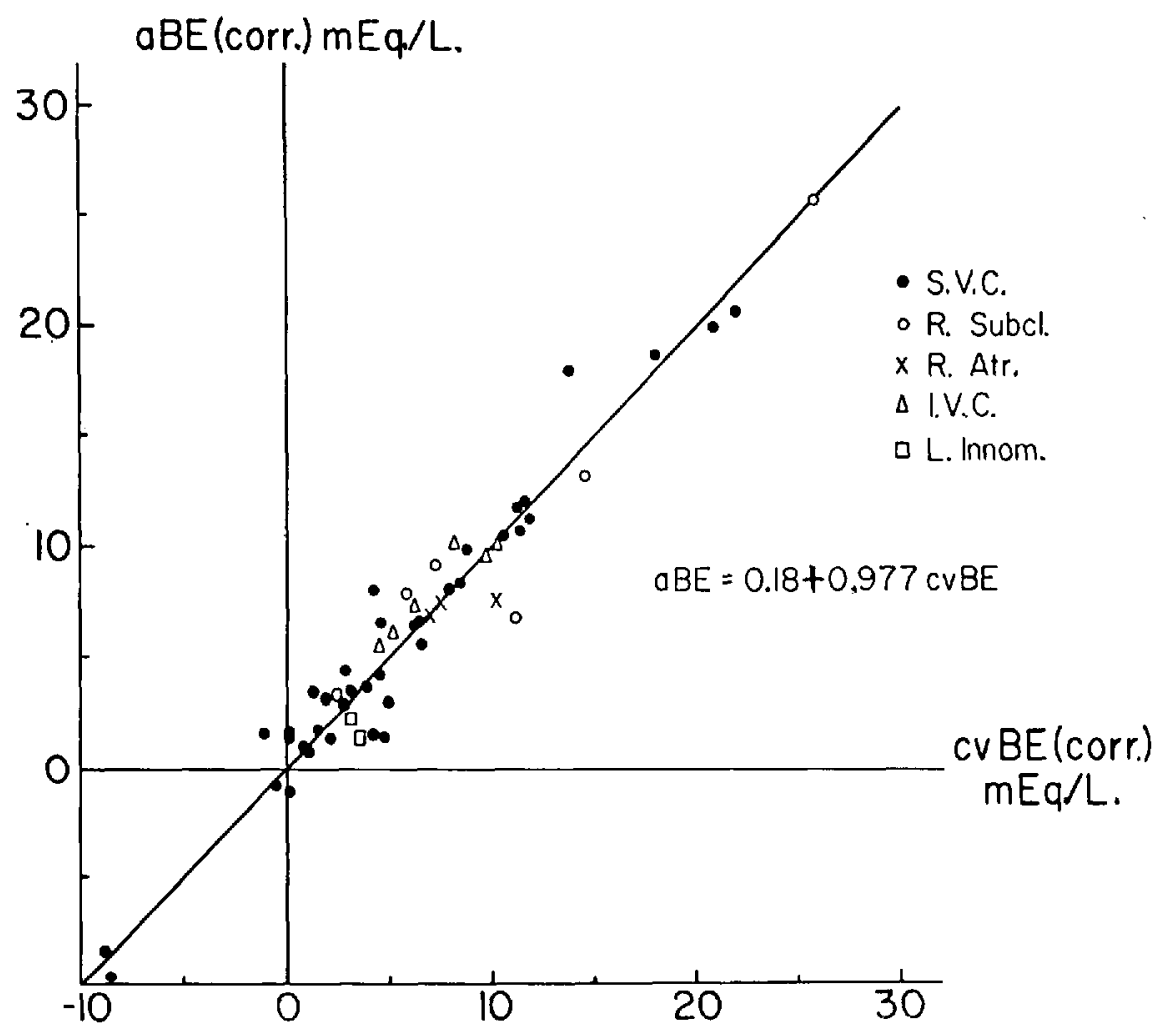

FIGUre 3. Comparison of arterial and central venous values for base excess, corrected for oxygen saturation, with their regression equation.

central venous $\mathrm{PCO}_{2}$ value, the possible error being comparable to that obtained by using the rebreathing technique. ${ }^{13}$

Central venous base excess proved to be equally useful (Figs. 2 and 3, Table III), although the range studied was biased. Figure 4 shows that most of the $\mathrm{pH}$ values are above the normal range and these reflect on the population which was studied. The distribution of the carbon dioxide tension values around $47 \mathrm{~mm}$. $\mathrm{Hg}$ (Fig. 1) and the positive value of the base excess noted in most of the patients (Figs. 2 and 3) indicate that the alkalosis was non-respiratory in origin. It was probably due to a combination of factors such as compensation for respiratory acidosis in patients with chronic respiratory disease, loss of hydrochloric acid from gastric suction, hypokalaemia, and diuretic therapy; it is a common finding in association with respiratory failure.

The lungs do not participate in the excretion of non-volatile acids and therefore one might expect no difference in the arterial and central venous base excess values. However, buffer base is formed on reduction of haemoglobin and is dependent upon oxygen saturation. Thus, there should be an a-cvs in base excess, the arterial value being lower than that of central venous blood. ${ }^{11}$

From the equation in Figure 2 and the mean a-cvs in Table III, it is apparent 


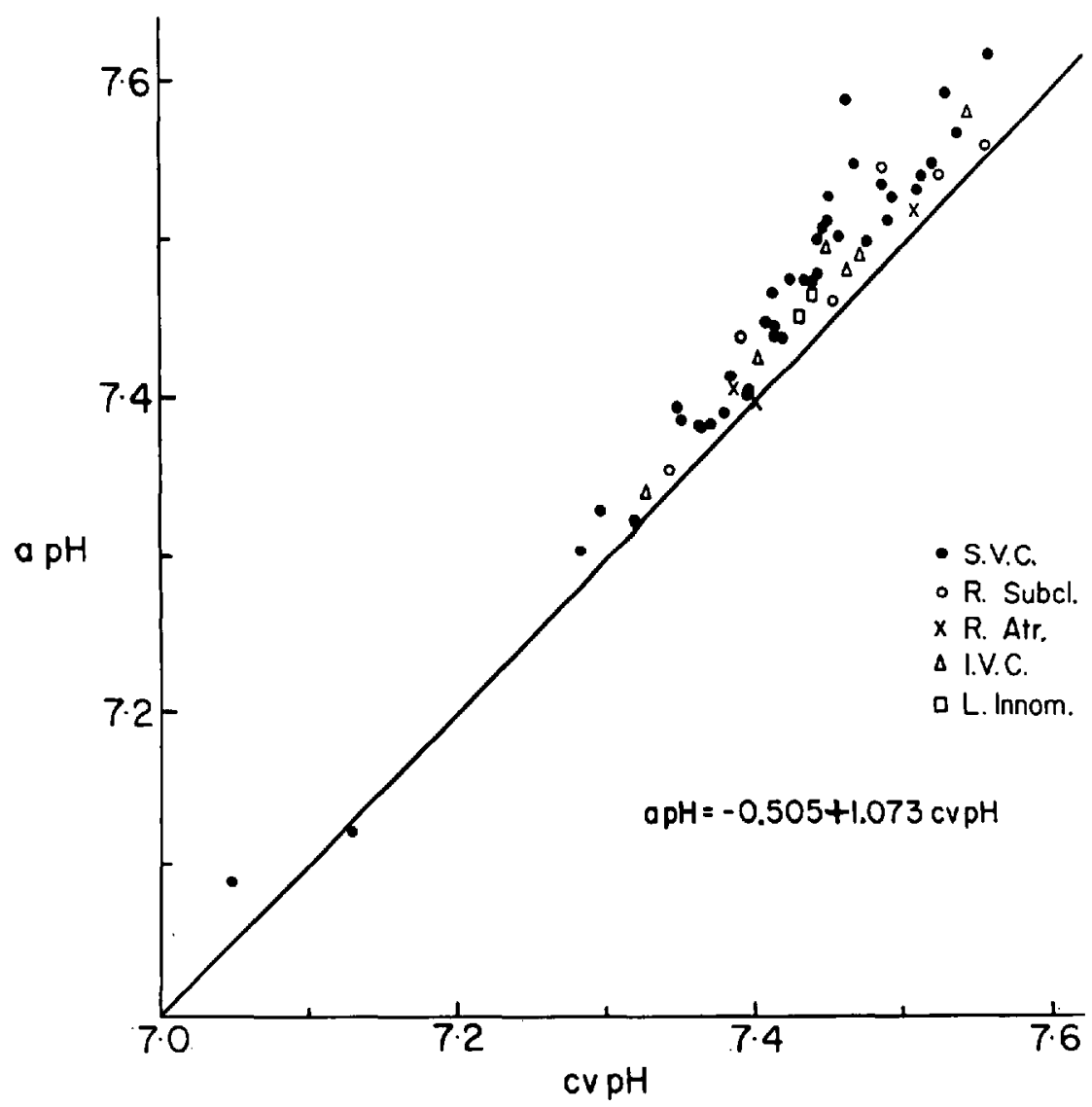

Figure 4. Comparison of arterial and central venous $\mathrm{pH}$ values, with their regression equation.

that there is an a-cv $\Delta$ of about $1 \mathrm{mEq}$. $/ \mathrm{L}$. It has been reported that the base formed on reduction of haemoglobin is constant in the $\mathrm{pH}$ range of 7.0 to $7.8,{ }^{19}$ and Siggaard-Andersen suggests that this amounts to

$$
\frac{0.3 \times \mathrm{Hgb}\left(100-\mathrm{So}_{2}\right)}{100} \mathrm{mEq} . / \mathrm{L} .{ }^{11}
$$

The a-cv $\Delta$ is eliminated after this correlation is applied (Fig. 3 and Table III). This is confirmed by the fact that the intercept value of $0.18 \mathrm{mEq} . / \mathrm{L}$. in the corrected base excess equation is not significantly different from zero; this in turn confirms the validity of the Siggaard-Andersen correction formula in the range studied.

The arterial base excess value and its 95 per cent confidence limits, predicted from an uncorrected central venous figure of, say, $0 \mathrm{mEq} . / \mathrm{L}$., would be -1 $\mathrm{mEq} . / \mathrm{L}$. with a possible range of $-3 \mathrm{mEq} . / \mathrm{L}$. to $1 \mathrm{mEq} . / \mathrm{L}$.-small enough to be very acceptable clinically. In fact, for clinical purposes, the small difference in base excess across the lungs can be ignored and the uncorrected value used. 


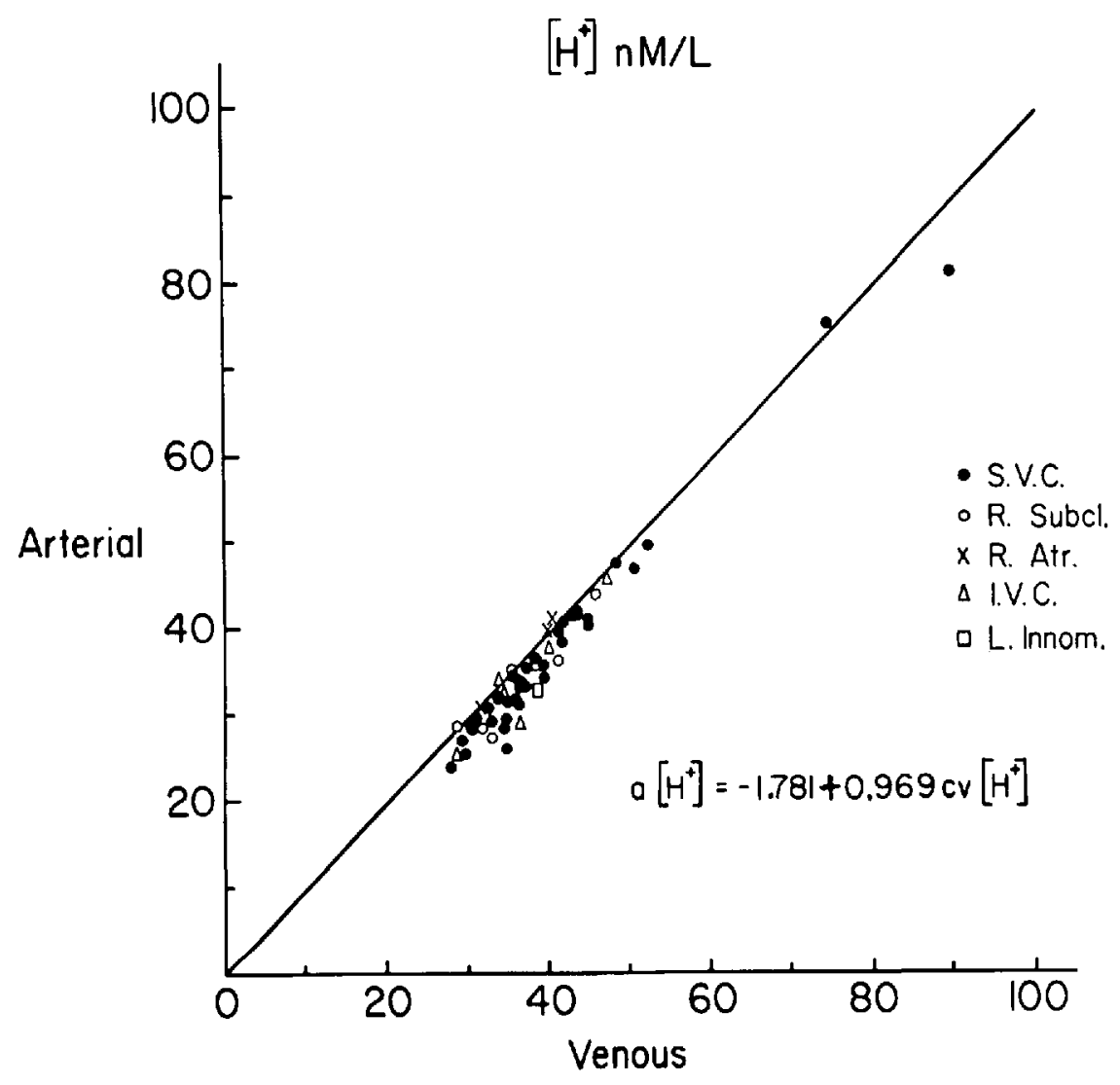

Figure 5. Comparison of arterial and central venous hydrogen ion concentration values, with their regression equation.

The scatter of values around the mean a-cvs for $\mathrm{pH}$ and $\left[\mathrm{H}^{+}\right]$is shown by the 95 per cent confidence limits in Table III. Thus a central venous $\mathrm{pH}$ of 7.36 would represent an arterial level of 7.4, when the mean a-cv $\Delta$ is applied. However, the 95 per cent confidence limits show that the true arterial value could be between 7.35 and 7.44 .

There is no general agreement as to the clinical usefulness of mixed venous oxygen levels as an index of oxygenation. Arterial-venous content differences depend not only on tissue requirement but on such additional factors as cardiac output, individual organ perfusion, and haemoglobin level. Correlations between arterial and venous contents are moderately good, but probably not usefully employed for prediction purposes, since the scatter of results is too great (Fig. 6 and Table V). Howell has pointed out that, in a given individual, mixed venous oxygen tension correlates well with the arterial saturation..$^{15}$ However, this is dependent upon constant haemoglobin level, oxygen consumption, and cardiac output.

Examination of the data for venous oxygen tension and arterial saturation in Table IV shows very poor over-all correlation in a mixed group of patients. 


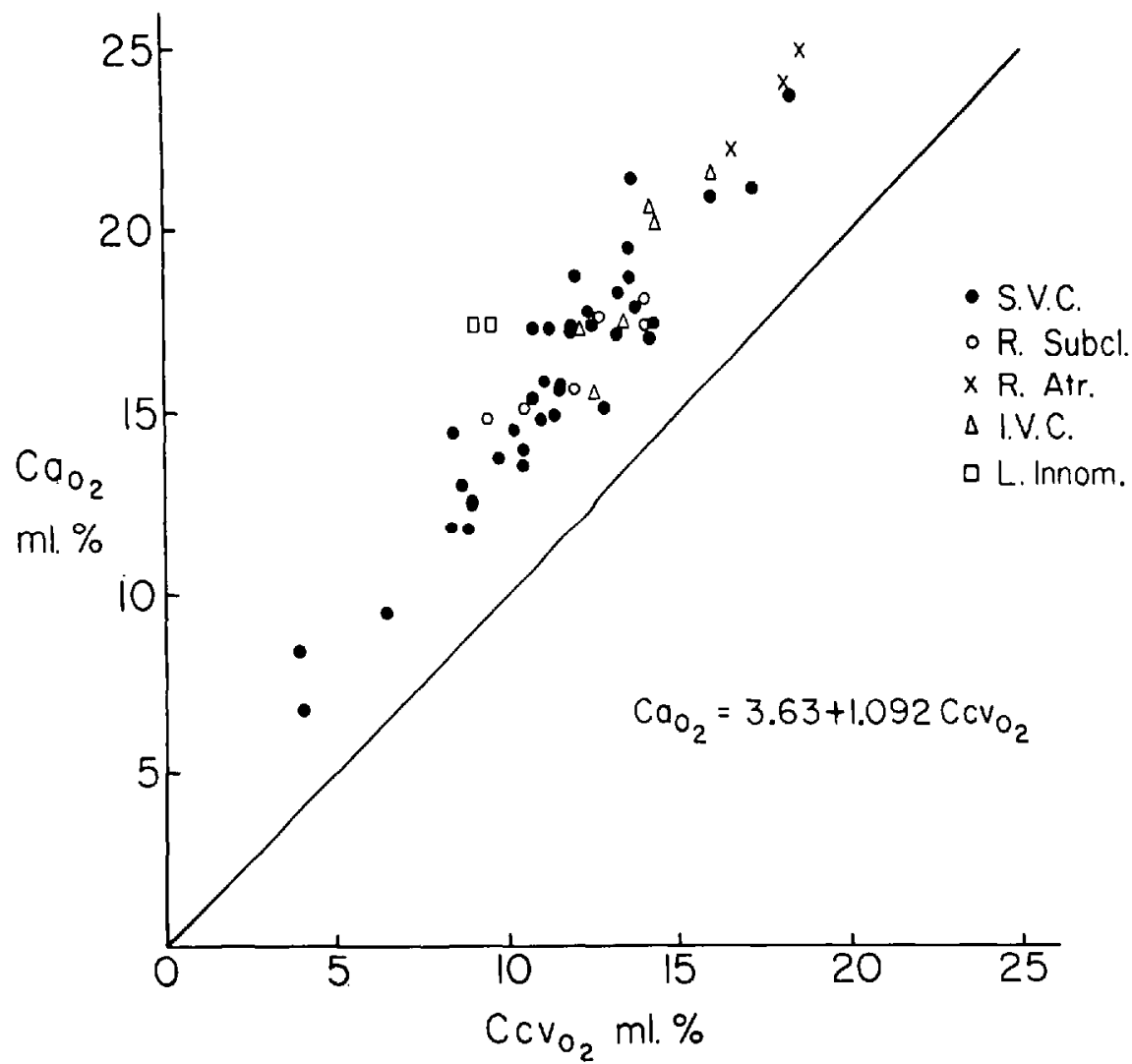

Figure 6. Comparison of central venous and arterial oxygen content values, with their regression equation.

Certainly there is poor correlation between arterial and central venous oxygen tensions and saturations (Figs. 7 and 8 ), and this is probably due, in addition to the factors mentioned above, to the alinearity of oxygen dissociation. Thus, when oxygen tension and haemoglobin are high, tissue uptake of oxygen may be achieved predominantly within the horizontal portion of the dissociation curve (patient number 1 (i)). The reverse is also the case-when tensions are low and the relationship between tension and saturation is on the vertical part of the curve, oxygen desaturation across the tissues can occur with only a small drop in tension (patient number 21). Thus similar oxygen uptakes may occur with markedly differing central venous oxygen tensions and arterial to central venous oxygen tension differences.

Since oxygen is delivered to the tissues by means of a head of diffusing pressure, venous oxygen tension is a reflection of this level of pressure at the end-tissue capillary. Below a certain threshold level, tissue hypoxia is a strong probability. However, when venous blood from all organs and tissues is mixed centrally, it may be almost impossible to draw meaningful conclusions from the resulting oxygen tension. ${ }^{16}$ Thus one concludes that central venous oxygen levels are probably not useful as clinical indices of oxygenation. 


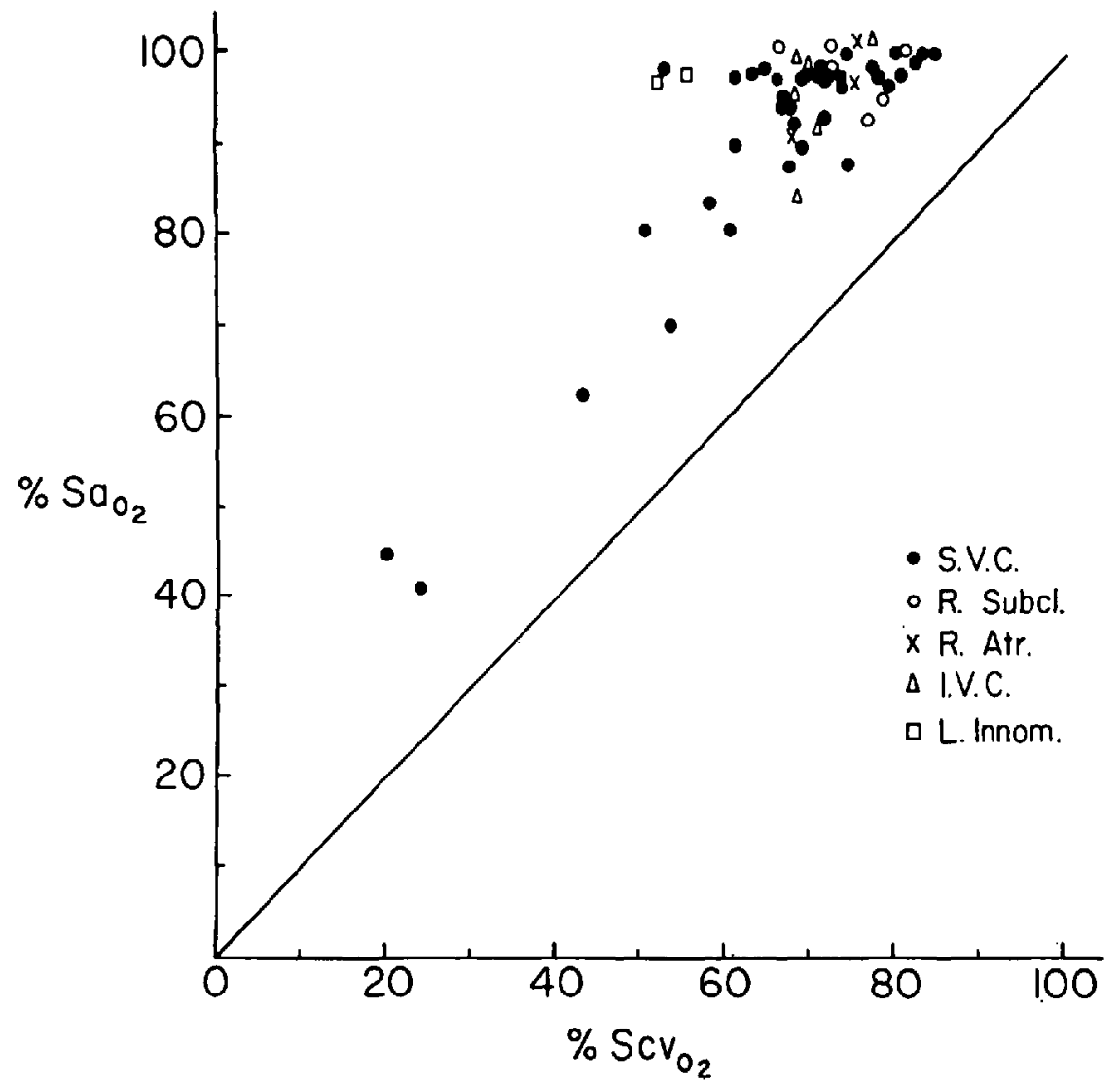

Figure 7. Comparison of arterial and central venous oxygen saturation values.

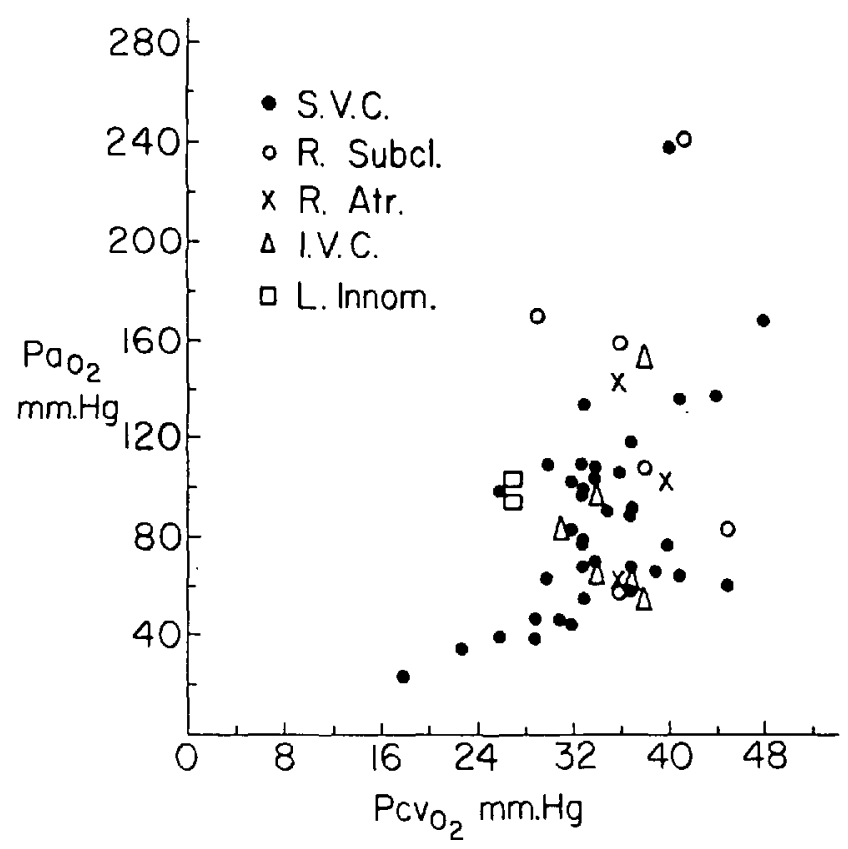

FIGURE 8. Comparison of arterial and central venous oxygen tension values. 


\section{SUMMARY}

A statistical study has been carried out, with the object of examining the usefulness of blood drawn from a central venous pressure line as an index of arterial acid-base status and oxygenation. Good correlation was observed between arterial and central venous values for carbon dioxide tension, base excess, $\mathrm{pH}$, hydrogen ion concentration, and oxygen content. However, the scatter of values was too great to recommend arterial predictions from any of the central venous values other than those for carbon dioxide tension, base excess and $\mathrm{pH}$. The subtraction of $6 \mathrm{~mm}$. $\mathrm{Hg}$ from a central venous carbon dioxide tension and the use of the actual central venous base excess value would give clinically useful indices of the true arterial levels. Arterial $\mathrm{pH}$ may be estimated by adding $0.04 \mathrm{pH}$ units to central venous values.

Central venous oxygen levels are not considered useful indices of arterial status.

\section{RÉSUMÉ}

Nous avons fait une étude statistique dans le but de vérifier s'il serait utile d'employer du sang retiré par un cathéter servant à prendre la tension veineuse centrale comme index de l'équilibre acide-base du sang artériel et de son oxygénation. Nous avons trouvé une relation assez étroite entre le sang artériel et le sang veineux central en ce qui concerne les données de la tension de $\mathrm{CO}_{2}$, l'excédent de bases, le $\mathrm{pH}$, la concentration en ion hydrogène et le contenu en oxygène. Toutefois, l'écart des données était trop considérable pour faire des prédictions artérielles à partir de n'importe quelle donnée du système veineux central à l'exception de celle de la tension du $\mathrm{CO}_{2}$, de l'excédent des bases et du pH. En soustrayant $6 \mathrm{~mm}$. $\mathrm{Hg}$ à la tension de $\mathrm{CO}_{2}$ du système veineux central et en employant la valeur actuelle du système veineux central en excédent de bases on pourrait obtenir des indices cliniques utiles des taux artériels réels. On peut estimer le $\mathrm{pH}$ artériel en ajoutent 0.04 unités de $\mathrm{pH}$ aux données veineux centrales.

Les taux d'oxygène du système veineux central ne fournissent pas d'indices utiles pour prédire les taux artériels.

\section{REFERENCES}

1. Sigganfd-Andersen, O.; Enger, K.; Jorgensen, K.; \& Astrup, P. A Micro-Method for Determination of $\mathrm{pH}$, Carbon Dioxide Tension, Base Excess and Standard Bicarbonate in Capillary Blood. Scandinav. J. Clin. Lab. Invest. 12: 172 (1960).

2. Cooper, E. A. \& SMITH, H. Indirect Estimation of Arterial $\mathrm{PCO}_{2}$. Anaesthesia. 16: 445 (1961).

3. Gambino, S. R. Collection of Capillary Blood for Simultaneous Determination of Arterial $\mathrm{pH}, \mathrm{CO}_{2}$ content, $\mathrm{PCO}_{2}$ and Oxygen Saturation. Am. J. Clin. Pathol. 35: 175 (1961).

4. Knudsen, E. J. \& Hansen, P. Carbon Dioxide Tensions in Non-arterialized Capillary and Arterial Blood during Anaesthesia. Act. Anaesth. Scandinav. 6: 29 (1962).

5. Woolf, C. R. The In Vitro and In Vivo Use of an Oxygen Microelectrode. J. Lab. Clin. Med. 69: 853 (1967).

6. Brooks, D. \& WynN, W. Use of Venous Blood for $\mathrm{pH}$ and Carbon Dioxide Studies, Especially in Respiratory Failure and during Anaesthesia. Lancet. 1: 227 (1959).

7. Harrison, E. M. \& Galloon, S. Venous Blood as an Alternative to Arterial Blood for the Measurement of Carbon Dioxide Tensions. Brit. J. Anaesth. 37: 13 (1965). 
8. Collis, J. \& Neaverson, M. A. Arterialized Venous Blood. Brit. J. Anaesth. 39: 883 (1967).

9. ZAHN, R. L. \& WeI, M. H. Central Venous Blood for Monitoring $\mathrm{pH}$ and $\mathrm{PCO}_{2}$ in the Critically Ill Patient. J. Thorac. Cardiovasc. Surg. 52: 105 (1966).

10. Severinghaus, J. W. Blood Gas Calculator. J. Appl. Physiol. 21: 1108 (1966).

11. SiggaARd-AnDERSEN, O. The Acid-Base Status of the Blood. 2nd ed., Baltimore: Williams and Wilkins (1964), p. 56.

12. Cournand, A.; Ritey, R. L.; Breed, E. S.; Baldwin, E. deF.; \& Richards, D. W. Jr. Measurement of Cardiac Output in Man Using the Technique of Catheterization of the Right Auricle or Ventricle. J. Clin. Invest. 24: 106 (1945).

13. Campeele, E. J. M. \& Howeil, J. B. L. Simple Rapid Methods of Estimating Arterial and Mixed Venous $\mathrm{PCO}_{2}$. Brit. Med. J. 1: 458 (1960).

14. Dill, D. B.; Edwards, H. T.; \& Consolazio, W. V. Blood as a Physicochemical System: XI. Man at Rest. J. Biol. Chem. 118: 635 (1937).

15. Howeld, J. B. L. Hypoxia in Man, in A Symposium on Oxygen Measurements in Blood and Tissues and Their Significance. J. P. Payne and D. W. Hill, eds. London: Churchill (1960).

16. LübBers, D. W. In A Symposium on Oxygen Measurements in Blood and Tissues and Their Significance (see ref. 15), p. 38. 